\title{
Improving Growth Performance of Jatropha curcas by Inducing Polyploidy through Colchicine Treatment
}

\author{
Syed Amir Manzoor 1*, Asim Riaz², Tanzeela Zafar3, Muhammad Hassan ${ }^{4}$, \\ Hafiz Muhammad Imran Umar4, Javed Hassan, Waseem Alam4, Saleh Muhammad ${ }^{5}$, \\ Mudassir Mahmood5, Hamza Sohail', Tanveer Aslam ${ }^{4}$, Feehan Hassan ${ }^{4}$, Fahim Abbas ${ }^{7}$, \\ Muhammad Faseeh Iqbal ${ }^{8}$ \\ ${ }^{1}$ Department of Forestry, Bahauddin Zakariya University, Multan, Pakistan \\ ${ }^{2}$ Department of Pharmacy Health and Well-Being, University of Sunderland, Sunderland, UK \\ ${ }^{3}$ Centre of Agricultural Biochemistry and Biotechnology, Faculty of Agriculture, University of Agriculture, \\ Faisalabad, Pakistan \\ ${ }^{4}$ Department of Plant Breeding \& Genetics, Bahauddin Zakariya University, Multan, Pakistan \\ ${ }^{5}$ Department of Entomology, Bahauddin Zakariya University, Multan, Pakistan \\ ${ }^{6}$ Department of Horticulture, Bahauddin Zakariya University, Multan, Pakistan \\ ${ }^{7}$ Nanjing Agriculture University, Nanjing, China \\ ${ }^{8}$ Department of Soil Science, Bahauddin Zakariya University, Multan, Pakistan \\ Email: *amir.kzd@gmail.com
}

Received 16 November 2015; accepted 11 April 2016; published 14 April 2016

Copyright (C) 2016 by authors and Scientific Research Publishing Inc.

This work is licensed under the Creative Commons Attribution International License (CC BY).

http://creativecommons.org/licenses/by/4.0/

c) (i) Open Access

\begin{abstract}
This study was planned to assess genetic variation in Jatropha curcas as affected by colchichine treatments. During the experiment, seeds of Jatropha curcas were collected from mature and healthy Jatropha plants and were soaked in different concentrations of colchicines. The second treatment was that of time of soaking (seeds were soaked in different concentrations for different time durations). The results clearly revealed that by increasing the concentration of colchicine treatment, parameters like stomatal density, and size of the guard cells were reduced.
\end{abstract}

\section{Keywords}

Jatropha, Polyploidy, Colchicine, Biofuel

\footnotetext{
*Corresponding author.
}

How to cite this paper: Manzoor, S.A., et al. (2016) Improving Growth Performance of Jatropha curcas by Inducing Polyploidy through Colchicine Treatment. American Journal of Plant Sciences, 7, 769-772. 


\section{Introduction}

The ever worsening energy crisis across the globe has triggered large scale research projects to identify economical, eco-friendly and sustainable sources of alternative fuel [1]. Of those numerous alternate options as suggested by scientists, biofuel is a promising source to combat the Damocles' sword of energy crisis. Jatropha curcas, one of the most productive and widely experimented biofuel tree plants has been known for its high oil content of seed and its potential to grow on marginal lands with lesser requirements of water and fertilizer [2]. The oil extracted from the seeds of this energy plant can be utilized for running low power engines and has been used to power different agricultural machinery [3].

Although, Jatorpha curcas seeds are pretty rich in oil content, it has shown low productivity of 625 - 1875 $\mathrm{kg} \cdot \mathrm{ha}^{-1} \cdot \mathrm{yr}^{-1}$ and lesser physical vigor [4]. It is therefore essential to carry out studies to figure out a suitable yield-increasing strategy for Jatropha plant. Since this tree plant has only limited genetic diversity, it becomes difficult to address the above mentioned issue through conventional breeding programs [5]. An alternate way to encounter this problem, as has been experimented by various researchers, is to induce mutation through seeds of Jatropha plant [6] to develop a new variety that may possibly give higher per hectare yield. Research studies have reported that application of colchicine increases the chromosome number and thus leads to bigger seed and flower sizes. As suggested by [7], cholchicine doubled the number of chromosomes in watermelon, thus leading to bigger seeds. [8] reported similar results for ginger plant when treated with colchicine.

Since Pakistan is one of those countries where climatic conditions largely support the growth of Jatropha crop, the current research therefore involves the use of colchicine to induce tetraploidy in Jatropha so as to develop a new variety that would possibly produce greater yield.

\section{Materials and Methods}

Seeds of Jatropha curcas were taken from 2 years old mature Jatropha plants. In order to mutate the seeds, different concentrations of colchicine were taken. Besides, seeds were soaked in those concentrations for different number of hours $(6,12,24,48)$. The colchicines concentrations were $0.25,1.25$ and $2.5 \mathrm{mM}$ and the set of seeds untreated with colchicine was taken as control in this experiment. Completely Randomized Design was used in this experiment in which there were three replications for each treatment while 10 seeds of Jatropha curcas were taken in each replication.

The treated seeds were grown in green house conditions. The experiment was conducted from March 2014 to May 2015 (90 days). At the end of the experiment, plant characteristics like stomatal density and the size (length and width) of guard cells were determined.

\section{Statistical Analysis and Experimental Design}

The experiment was framed using completely randomized design (CRD) ANOVA (Analysis of variance) was carried out and mean values of treatments were compared using DMRT (Duncan’s multiple range test).

\section{Results and Discussion}

As depicted in Table 1, stomatal density of Jatropha curcas does not seem to have been significantly affected by the colchicines treatments. Although the stomatal density has increased with increasing the colchicines concentration, the highest stomatal density was achieved with treatment T11 (1.25 mM, 24 hours of soaking). Stomatal density is an important parameter while considering the growth performance of a particular plant species. Since stomata is the gateway of gaseous exchange for plants, higher density of stomata leads to more vigorous growth of plants [9].

Length of the guard cells was significantly affected by the application of colchicine. Length of the guard cells seems to have been minimum at lower and highest concentrations of colchicine. At moderate concentrations, maximum value was obtained for this parameter. Highest value for the length of the guard cells was obtained at treatment T6 (0.25 mM, 12 hours of soaking). Similarly, the width of the guard cell had also shown significant response to the application of cholchicine. The induction of tetraploidy brought significant difference to the plant growth by affecting the width and the length of the guard cells. The width of the guard cells was recorded maximum in treatment T3 (0 mM, 24 hour). Although there was no trend observed in the reading, yet an increase in the concentration and soaking duration seemed to have negatively affected the width of the guard cells 
Table 1. Effect of colchicine application on various growth parameters of Jatropha curcas.

\begin{tabular}{cccccc}
\hline Treatment & $\begin{array}{c}\text { Soaking } \\
\text { Concentration }\end{array}$ & $\begin{array}{c}\text { Soaking } \\
\text { Duration }\end{array}$ & $\begin{array}{c}\text { Stomatal } \\
\text { Density }\end{array}$ & $\begin{array}{c}\text { Length of } \\
\text { Guard Cell }\end{array}$ & $\begin{array}{c}\text { Width of } \\
\text { Guard Cell }\end{array}$ \\
\hline T1 (Control) & $0 \mathrm{mM}$ & 6 Hours & $9.12 \pm 1.2$ & $0.035 \pm 0.00012 \mathrm{ab}$ & $0.025 \pm 0 \mathrm{c}$ \\
$\mathrm{T} 2$ & $0 \mathrm{mM}$ & 12 Hours & $8.91 \pm 0.81$ & $0.038 \pm 0.00001 \mathrm{ab}$ & $0.04 \pm 0 \mathrm{ab}$ \\
T3 & $0 \mathrm{mM}$ & 24 Hours & $9.21 \pm 00$ & $0.041 \pm 0.00032 \mathrm{ab}$ & $0.044 \pm 0.0004 \mathrm{a}$ \\
T4 & $0 \mathrm{mM}$ & 48 Hours & $9.81 \pm 0.23$ & $0.04 \pm 0.0014 \mathrm{ab}$ & $0.045 \pm 0.0003 \mathrm{a}$ \\
T5 & $0.25 \mathrm{mM}$ & 6 Hours & $10.59 \pm 0.13$ & $0.037 \pm 0.00014 \mathrm{ab}$ & $0.039 \pm 0.0004 \mathrm{~b}$ \\
T6 & $0.25 \mathrm{mM}$ & 12 Hours & $10.98 \pm 0.98$ & $0.044 \pm 0.00019 \mathrm{a}$ & $0.04 \pm 0 \mathrm{ab}$ \\
T7 & $0.25 \mathrm{mM}$ & 24 Hours & $11.24 \pm 1.1$ & $0.036 \pm 0.00018 \mathrm{ab}$ & $0.036 \pm 0.0011 \mathrm{ab}$ \\
T8 & $0.25 \mathrm{mM}$ & 48 Hours & $11.12 \pm 0.35$ & $0.036 \pm 0.00051 \mathrm{ab}$ & $0.037 \pm 0 \mathrm{ab}$ \\
T9 & $1.25 \mathrm{mM}$ & 6 Hours & $13 \pm 1.2$ & $0.034 \pm 0.00006 \mathrm{ab}$ & $0.035 \pm 0.0001 \mathrm{ab}$ \\
T10 & $1.25 \mathrm{mM}$ & 12 Hours & $12.85 \pm 1.23$ & $0.039 \pm 0.00019 \mathrm{~b}$ & $0.034 \pm 0.0003 \mathrm{ab}$ \\
T11 & $1.25 \mathrm{mM}$ & 24 Hours & $13.1 \pm 0.94$ & $0.034 \pm 0.00051 \mathrm{ab}$ & $0.034 \pm 0 \mathrm{ab}$ \\
T12 & $1.25 \mathrm{mM}$ & 48 Hours & $12.21 \pm 0.99$ & $0.034 \pm 0.00017 \mathrm{ab}$ & $0.035 \pm 0.0003 \mathrm{ab}$ \\
T13 & $2.5 \mathrm{mM}$ & 6 Hours & $12.23 \pm 0.31$ & $0.036 \pm 0.0003 \mathrm{ab}$ & $0.038 \pm 0.0012 \mathrm{~b}$ \\
T14 & $2.5 \mathrm{mM}$ & 12 Hours & $12.48 \pm 1.51$ & $0.04 \pm 0.00041 \mathrm{~b}$ & $0.036 \pm 0 \mathrm{ab}$ \\
T15 & $2.5 \mathrm{mM}$ & 24 Hours & $12.1 \pm 1.00$ & $0.034 \pm 0.0003 \mathrm{ab}$ & $0.037 \pm 0.0001 \mathrm{~b}$ \\
T16 & $2.5 \mathrm{mM}$ & 48 Hours & $12.34 \pm 0.87$ & $0.038 \pm 0.00021 \mathrm{~b}$ & $0.04 \pm 0 \mathrm{a}$ \\
\hline
\end{tabular}

in Jatropha plants. As suggested by [10], the significant difference in width and length of guard cells was possibly due to the fact that most of the normal seeds were diploid (colchicine was not applied). However, when different concentrations of colchicine were applied, it would have resulted in different types of mixploidy. Induction of tetraplidy, as would be expected by application of colchicine treatments, would have caused difference in the size of guard cells among the mutant seed plants.

This research study has highlighted the possible outcomes of application of colchichone on Jatropha seeds through seed soaking. The study showed that the application of colchicine brought changes in the ploidy level and the results were reflected in terms of variations in the value of width and length of guard cells on mutated Jatropha plant leaves. The growth parameters of the tetraploid plant were however lower as compared to the normal normal Jatropha plants which indicated that the subsequent yield would also be lower as compared to the normal Jatropha plants.

\section{References}

[1] Peerapong, P. and Limmeechokchai, B. (2009) Exergetic and Thermoeconomic Analyses of the Rice-Husk Power Plant in Thailand. Journal of Metals, Materials and Minerals, 19, 9-14.

[2] Ginting, C. and Maryono, T. (2009) Physic Nut (Jatropha curcas L.) Diseases in Lampung Province. Biotropia, 16, 45-54.

[3] Sidhinew, K. (2002) Fuel Substitution from Plant, Sustainability of Energy. Feature Magazine, 207, 72-92.

[4] Pasbhut, R. and Sutiponpiboon, S. (2001) Sheets for Training "Physic Nut Oil as Energy Substituition”. Chai Nart Agricultural Mechanical Extension Center, Thailand, 27-28 February 2001.

[5] Songsri, P., Suriharn, B., Sanitchon, J., Srisawangwong, S. and Kesmala, T. (2011) Effects of Gramma Radiation on Germination and Growth Characteristics of Physic Nut (Jatropha curcas L.). Journal of Biological Sciences, 11, 268274. http://dx.doi.org/10.3923/jbs.2011.268.274

[6] Sujatha, M., Makkar, H.P.S. and Becker, K. (2006) Shoot Bud Proliferation from Axillary Nodes and Leaf Sections of Non-Toxic Jatropha curcas L. Plant Growth Regulation, 47, 83-90. http://dx.doi.org/10.1007/s10725-005-0859-0 
[7] Henderson, W.R. (1977) Effect of Cultivar. Polyploidy and Reciprocal Hybridization on Characters Important in Breeding Triploid Seedless Watermelon Hybrids. Journal of the American Society for Horticultural Science, 94, 367369.

[8] Adaniya, S. and Shirai, D. (2001) In Vitro Induction of Tetraploid Ginger (Zingiber offi Cinale Roscoe) and Its Pollen Fertility and Germinability. Scientia Horticulturae, 88, 277-287. http://dx.doi.org/10.1016/S0304-4238(00)00212-0

[9] Hamill, S.D., Smith, M.K. and Dodd, W.A. (1992) In Vitro Induction of Banana Autotetraploidy by Colchicine Treatment of Microproagated Diploids. Australian Journal of Botany, 40, 887-896. http://dx.doi.org/10.1071/BT9920887

[10] Kadota, M. and Niimi, Y. (2002) In Vitro Induction of Tetraploid Plants from a Diploid Japanese Pear Cultivar (Pyrus pyrifolia N. cv. Hosui ). Genetics and Genomics, 21, 282-286. http://dx.doi.org/10.1007/s00299-002-0509-1 